\title{
Pelatihan menu sehat balita dalam upaya pencegahan stunting di Desa Ranah Singkuang Kecamatan Kampar
}

\author{
Deviona*, Nelvia, Chairul, \& Yunandra \\ Universitas Riau \\ *deviona73@lecturer.unri.ac.id
}

\begin{abstract}
Abstrak. Desa Ranah Singkuang adalah salah satu dari 10 desa yang tergolong desa gizi buruk (stunting) di wilayah Kabupaten Kampar dengan persentase sebesar $24 \%$. Pemerintah Kabupaten Kampar telah melakukan pencegahan kondisi stunting pada tahun 2018 sampai dengan 2019. Kondisi stunting bila tidak ditangani dengan segera akan mempengaruhi kualitas sumber daya manusia di masa mendatang. Kondisi stunting menyebabkan anak tidak tumbuh normal, IQ rendah, mudah terserang penyakit infeksi akibatnya produktivitas rendah dan sulit bersaing dalam dunia kerja. Tujuan kegiatan pengabdian masyarakat ini adalah transfer of knowledge kepada masyarakat di Desa Ranah Singkuang, meningkatkan pengetahuan dan kemampuan masyarakat desa dalam hal pengolahan berbagai macam produk berbahan dasar ikan yang memiliki nilai gizi yang tinggi yang laku di pasaran dalam rangka mendorong peningkatan perekonomian masyarakat, memberikan pengetahuan tentang kesehatan anak dengan cara melakukan penyuluhan kepada masyarakat dan pelatihan menu sehat anak agar nafsu makannya meningkat. Hasil yang dicapai dari kegiatan pengabdian masyarakat ini yaitu masyarakat lebih memahami pentingnya gizi bagi anak balita terutama menjelang umur 1000 hari dan masyarakat dapat melakukan pengolahan makanan berbahan dasar ikan sehingga permasalahan stunting di desa tersebut dapat dicegah.
\end{abstract}

Kata kunci: Desa Ranah Singkuang, stunting, menu, gizi

\begin{abstract}
Ranah Singkuang is one of 10 villages classified as stunting villages in the Kampar regency area with a percentage of 24\%. The Kampar District Government has done prevention programs on stunting condition from 2018 to 2019. If not treated immediately, the condition of stunting will affect the quality of human resources in the future. The condition of stunting causes children not to grow normally, low IQ, susceptible to infectious diseases as a result of low productivity, and difficulty competing in the world of work. The purpose of this community service activity is the transfer of knowledge to the community in Ranah Singkuang village, increasing the knowledge and ability of village community in terms of processing various kinds of fish-based products that have high nutritional values that are salable in the market in order to boost the community's economy, provide knowledge about children's health by providing education to the community and training children's healthy menus so that their appetite increases. The result achieved from this community service activity are that the community understands more about the importance of nutrition for toddlers especially before the age of 1000 days and the community can process fish-based food, so that stunting problems in the village can be prevented.
\end{abstract}

Keywords: Ranah Singkuang Village, stunting, menu, nutrition

\author{
To cite this article: Deviona., Nelvia., Chairul., \& Yunandra. 2020. Pelatihan menu sehat balita dalam upaya \\ pencegahan stunting di Desa Ranah Singkuang Kecamatan Kampar. Unri Conference Series: Community \\ Engagement 2: 526-530. https://doi.org/10.31258/unricsce.2.526-530
}




\section{PENDAHULUAN}

Desa Ranah Singkuang adalah desa di kecamatan Kampar, kabupaten Kampar, provinsi Riau. Desa ini terletak di sebelah barat kota Pekanbaru dengan jarak $45 \mathrm{~km}$, sebelah utara berbatasan dengan desa Penyasawan, sebelah selatan dengan desa Siabu, sebelah timur dengan desa Penyasawan dan sebelah Barat dengan Bukit Ranah (Siabu). Desa Ranah Singkuang berjarak $5 \mathrm{~km}, 25 \mathrm{~km}$ dan $30 \mathrm{~km}$ masing-masing dari ibu kota Kecamatan, kabupaten dan ibukota Provinsi (Pekanbaru).

Masyarakat Desa Ranah Singkuang mayoritas bekerja sebagai petani. Desa Ranah Singkuang merupakan desa yang potensi pertaniannya cukup besar yang selama ini hanya didominasi tanaman kelapa sawit dan karet. Padahal peluang budidaya tanaman palawija dinilai cukup besar, dikarenakan lahan kosong yang masih luas. Disamping itu, dibidang perikanan juga memiliki potensi cukup besar, banyak tambak ikan di desa Ranah Singkuang. Selama ini, belum banyak dimanfaatkan dalam bentuk produk olahan dari ikan seperti bakso, pempek ikan dan nugget.

Desa Ranah Singkuang adalah salah satu dari 10 desa yang tergolong desa gizi buruk (stunting) di wilayah Kabupaten Kampar dengan persentase sebesar $24 \%$. Pemerintah Kabupaten Kampar telah melakukan pencegahan kondisi stunting pada tahun 2018 sampai dengan 2019. Definisi stunting merupakan permasalahan gizi dengan angka kejadian 150, 8 juta anak $(22,2 \%)$ yang mengganggu keberlangsungan bermasyarakat di dunia. Penurunan angka stunting merupakan salah satu tujuan dari Ambitious World Health Assembly dengan target penurunan 40\% pada tahun 2025 (UNICEF/ WHO/The World Bank 2019; WHO 2014). Hasil survey awal di Desa Ranah Singkuang menunjukkan bahwa masih terdapat sebanyak $23 \%$ anak yang menderita stunting. Kondisi stunting bila tidak ditangani dengan segera akan mempengaruhi kualitas sumber daya manusia di masa mendatang. Kondisi stunting menyebabkan anak tidak tumbuh normal, IQ rendah, mudah terserang penyakit infeksi akibatnya produktivitas rendah dan sulit bersaing dalam dunia kerja. Stunting yang terjadi pada masa anak merupakan faktor risiko meningkatnya angka kematian, kemampuan kognitif, dan perkembangan motorik yang rendah serta fungsi-fungsi tubuh yang tidak seimbang (Allen \& Gillespie, 2001).

Stunting dipengaruhi oleh pola asuh, cakupan dan kualitas pelayanan kesehatan, lingkungan, serta ketahanan pangan. Stunting dapat diatasi dengan memberikan gizi cukup pada 1000 hari awal kehidupan seorang anak. Periode 1000 hari pertama kehidupan merupakan periode emas sekaligus periode kritis bagi seseorang (windows of opportunity). Kondisi kesehatan dan gizi ibu sebelum dan saat kehamilan, postur tubuh ibu, jarak kehamilan yang cenderung dekat, ibu yang masih remaja dan asupan nutrisi yang kurang saat kehamilan mempengaruhi pertumbuhan janin dan risiko terjadinya stunting (Djauhari, 2017). Seorang ibu yang bertindak sebagai pengasuh dan pemasok gizi kepada anak harus memahami pola makan yang mengandung gizi cukup dan baik. Oleh karena itu, peran ibu dan penyebab dari stunting tersebut sangat berpengaruh pada kejadian stunting (Aridiyah, Rohmawati, Ririanty, 2015). Kualitas pelayanan kesehatan yang baik turut berperan dalam mencegah terjadinya stunting pada anak karena kesehatan sangat menentukan nafsu makan seorang anak yang akhirnya mempengaruhi gizi anak. Lingkungan yang kurang baik akan mendorong anak usia dini mudah terserang penyakit infeksi. Ketahanan pangan yang berarti kecukupan pangan merupakan komponen yang paling penting dalam mencegah terjadinya stunting pada balita.

Pemerintah telah menetapkan strategi lima pilar penanganan stunting, yaitu (1) komitmen dan vaksi kepemimpinan, (2) kampanye nasional dan komunikasi perubahan perilaku, (3) konvergensi, koordinasi, konsolidasi program pusat, daerah dan desa, (4) gizi, dan ketahanan pangan, dan (5) pemantauan dan evaluasi. Berdasarkan hasil penelitian Trisnawati, et.al (2016) menunjukkan asupan gizi pada balita sebagian besar kurang. Terdapat banyak balita dengan kategori asupan kurang dikarenakan balita makan secara tidak teratur, terutama untuk konsumsi nasi. Berdasarkan hasil observasi dimana balita merupakan masa sulit dalam pemberian makan anak, karena anak sudah mulai aktif dan pemantauan orang tua juga sudah mulai berkurang. Menurut Prabatini (2010), berbagai cara memasak dapat mempengaruhi kandungan nutrisi didalam makanan yang dimasak.

Oleh karena itu, pelatihan menu makan sehat balita perlu untuk disosialisasikan kepada masyarakat di Desa Ranah Singkuang agar mereka lebih memahami pentingnya peranan gizi yang seimbang untuk batita maupun balita serta mereka mampu memanfaatkan bahan alami yang aman, mudah didapat, dan kaya gizi yang dapat dijadikan olahan makanan penambah nafsu makan anak. Tujuan kegiatan pengabdian masyarakat ini adalah transfer knowledge kepada masyarakat di desa Ranah Singkuang, meningkatkan pengetahuan dan kemampuan masyarakat desa dalam hal pengolahan berbagai macam produk berbahan dasar ikan yang memiliki nilai gizi yang tinggi yang laku di pasaran dalam rangka mendorong peningkatan perekonomian masyarakat, 
memberikan pengetahuan tentang kesehatan anak dengan cara melakukan penyuluhan kepada masyarakat dan pelatihan menu sehat anak agar nafsu makannya meningkat.

\section{METODE PENERAPAN}

Kegiatan pengabdian masyarakat ini dilaksanakan di Desa Ranah Singkuang, Kecamatan Kampar, Kabupaten Kampar, Riau pada bulan Mei - Juli 2020. Sasaran program kegiatan ini adalah masyarakat Desa Ranah Singkuang terutama ibu posyandu dan PKK yang berminat dalam pelatihan nutrisi serta pengolahan makanan. Kegiatan ini menggunakan tiga metode pelaksanaan yaitu penyuluhan, pelatihan, dan perlombaan. Kegiatan penyuluhan diawali dengan penyerahan buku saku stunting yang sudah dibuat oleh tim pengabdian kepada kader posyandu untuk dapat disosialisasikan kepada masyarakat dan selanjutnya penyuluhan mengenai gizi anak dilakukan dengan mendatangkan narasumber sebagai pembicara. Penyuluhan ini diharapkan dapat meningkatkan kesadaran dan pemahaman masyarakat untuk lebih memperhatikan gizi anak terutama 1000 hari pertama kehidupannya sehingga tidak dijumpai lagi kasus stunting di Desa Ranah Singkuang. Kegiatan pelatihan dilakukan berdasarkan materi penyuluhan meliputi pelatihan pembuatan menu sehat balita berbahan dasar sumber karbohidrat, protein, serta bahan lain yang mengandung gizi yang tinggi. Kegiatan pelatihan ini dilakukan dalam bentuk demonstrasi pembuatan 5 menu makan sehat oleh tim pengabdian yaitu meliputi pembuatan bubur beras merah, bakso ikan, nugget sayur, pudding ubi ungu, dan pudding jagung serta juga dilakukan pelatihan pembuatan tempe. Hal ini sejalan dengan potensi daerah berupa banyaknya usaha kolam ikan dan kebun-kebun warga. Kegiatan perlombaan menu makan sehat dilakukan sebagai evaluasi keberhasilan dari kegiatan pelatihan yang telah dilakukan sebelumnya. Kegiatan perlombaan diawali dengan penentuan peserta lomba yaitu setiap RW di Desa Ranah Singkuang mengirimkan 1 tim perwakilan yang terdiri atas 3 orang. Perlombaan dilaksanakan di aula Desa ranah Singkuang dalam waktu 2 jam dan diakhir acara dilakukan pembagian hadiah.

\section{HASIL DAN KETERCAPAIAN SASARAN}

\section{Penyuluhan gizi anak}

Kegiatan penyuluhan gizi ini dilakukan dengan mendatangkan narasumber yaitu ibu Dr. Deviona, SP, MP dan ibu Dr. Ir. Nelvia M.P. Pada kegiatan ini, narasumber menyampaikan mengenai pentingnya pemenuhan gizi balita sesuai dengan umurnya. Keberhasilan kegiatan penyuluhan dapat dilihat dari peningkatan pengetahuan dari tidak tahu menjadi tahu dan dari tahu menjadi lebih tahu, peningkatan keterampilan dari tidak mampu menjadi mampu, peningkatan sikap dari tidak mau menjadi mau (Ibrahim, 2003). Keberhasilan kegiatan penyuluhan ini dapat dilihat dari meningkatnya kesadaran dan pemahaman masyarakat untuk lebih memperhatikan gizi anak terutama 1000 hari pertama kehidupannya sehingga tidak dijumpai lagi kasus stunting di Desa Ranah Singkuang.

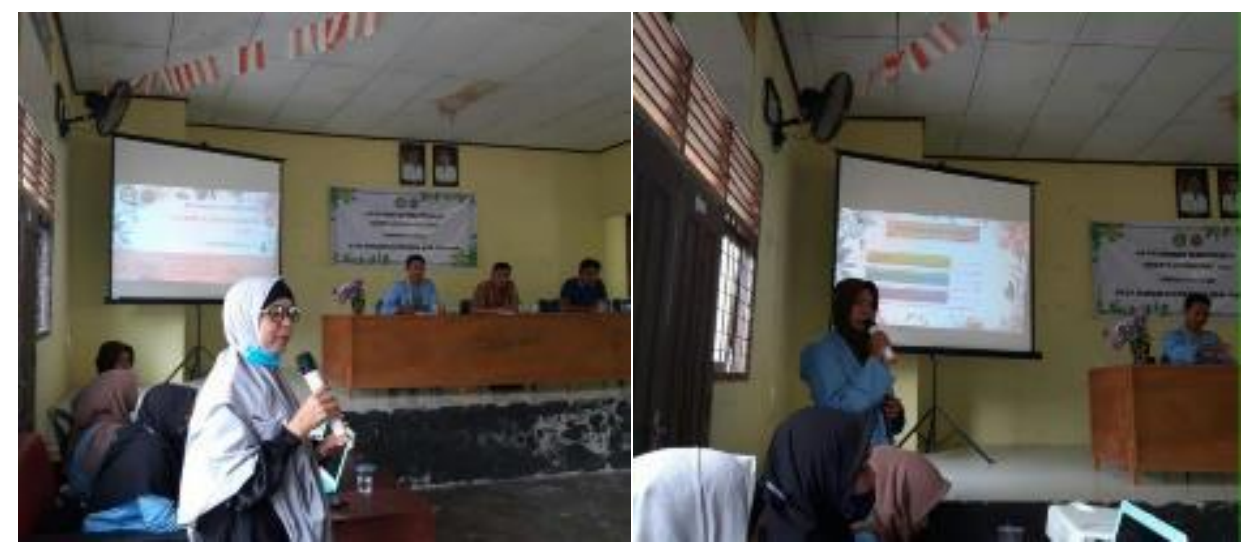

Gambar 1. Penyuluhan Gizi Anak

\section{Pelatihan olahan menu makan sehat balita}

Kegiatan pelatihan dilakukan dalam bentuk praktik. Tim pengabdian masyarakat membuat aneka menu makanan sehat untuk balita yaitu nugget sayur, bakso ikan, bubur beras merah, pudding jagung manis, dan pudding ubi ungu. Pembuatan menu makanan sehat balita ini dilakukan didepan kader posyandu serta ibu-ibu 
warga Desa Ranah Singkuang dengan cara mendemonstrasikan alat dan bahan, langkah kerja serta kandungan gizi yang terdapat pada setiap menu makanan. Bersamaan dengan kegiatan demonstrasi menu makanan sehat tersebut, tim pengabdian masyarakat juga membagikan produk olahan menu makanan sehat tersebut dalam bentuk produk yang sudah jadi. Pada akhir kegiatan pelatihan ini juga dilakukan sesi tanya jawab dan pembagian doorprize kepada warga yang dapat menjawab pertanyaan yang diajukan oleh tim pengabdian. Setelah kegiatan pelatihan dilaksanakan, ibu-ibu warga Desa Ranah Singkuang menjadi lebih memahami dan lebih termotivasi untuk menerapkan berbagai menu makan sehat bergizi untuk anak-anak mereka dirumah.

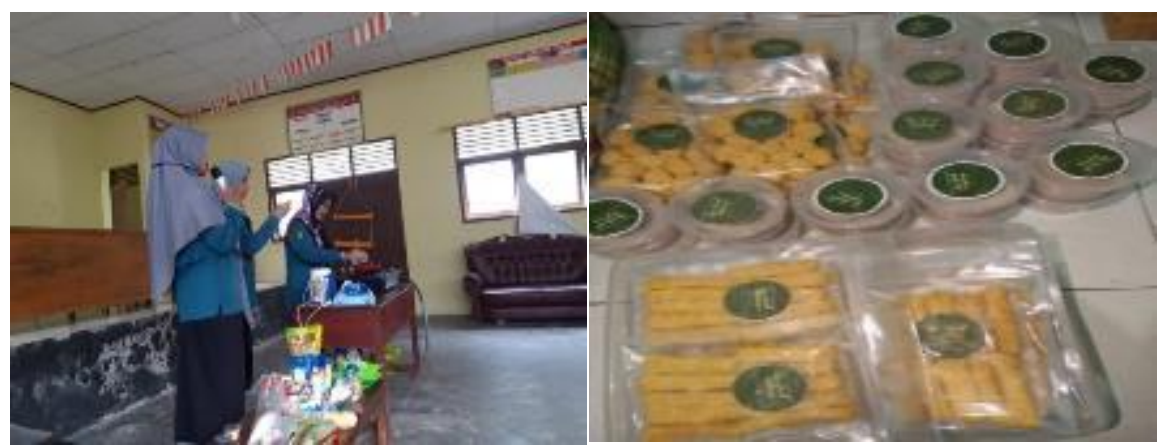

Gambar 2. Pelatihan Olahan Menu Makan Sehat Balita

\section{Perlombaan olahan menu makan sehat balita}

Kegiatan perlombaan olahan menu sehat balita yang diadakan oleh tim pengabdian masyarakat memberi dampak baik dalam pengembangan pengetahuan ibu-ibu warga Desa Ranah Singkuang untuk mengolah sumber daya alam berupa bahan makanan yang mengandung gizi tinggi di Desa tersebut sebagai sumber pemenuhan asupan gizi balita. Manfaat setelah perlombaan ini adalah berubahnya pemikiran ibu-ibu warga Desa Ranah Singkuang bahwa balita membutuhkan makanan sehat untuk tumbuhkembangnya.

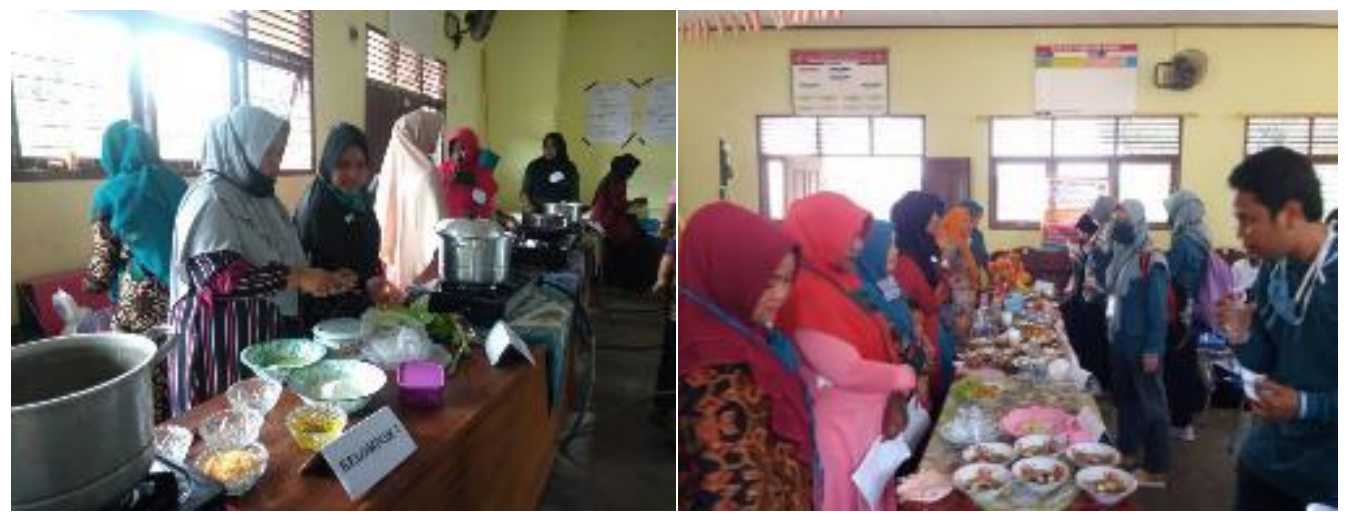

Gambar 3. Perlombaan Olahan Menu Makan Sehat Balita

\section{KESIMPULAN}

Kegiatan pengabdian kepada masyarakat yang berupa pelatihan menu sehat balita dalam upaya pencegahan stunting di Desa Ranah Singkuang, Kecamatan Kampar, Kabupaten Kampar telah meningkatkan pengetahuan (knowledge) dan kemampuan masyarakat terutama ibu rumah tangga mengenai pentingnya pemenuhan gizi anak terutama pada 1000 hari pertama kehidupan (HPK) serta meningkatkan kemampuan ibu rumah tangga dalam hal pengolahan potensi desa yaitu ikan menjadi sumber protein hewani dalam pemenuhan gizi anak dan dapat juga dijadikan berbagai produk olahan yang memiliki nilai ekonomi yang tinggi sehingga dapat dijadikan sebagai sumber pendapatan tambahan bagi keluarga. 


\section{DAFTAR PUSTAKA}

Allen, L.H dan Gillespie, S.R. 2001. What Works? A Review of The Efficacy and Effectiveness of Nutrition Intervensions. Manila: ABD.

Aridiah, Okky F. Ninna R. \& Mury Ririanty. 2015. Faktor-faktor yang Mempengaruhi Kejadian Stunting Pada Anak Balita di Wilayah Pedesaan dan Perkotaan. Jurnal Pustaka Kesehatan, 3(1).

Djauhari, Thantowi. 2017. Gizi Dan 1000 HPK. Siantika Medika, 13(20), 125. http:/ejournal.umm.ac.id/index.php/sainmed/article/view/5554

Prabatini, D. 2010. Makanan Pendamping ASI. Yogyakarta: Nuha Medika.

Trisnawati, Yuli, dkk. 2016. Studi Deskriptif Pengetahuan Dan Sikap Ibu Hamil Tentang Gizi 1000 Hari Pertama Kehidupan Di Puskesmas Sokaraja Kabupaten Banyumas. Jurnal Kebidanan, VIII(02).

UNICEF/ WHO/The World Bank. 2019. Levels and Trends in Child Malnutrition - Unicef WHO the World Bank Joint Child Malnutrition Estimates, Key Findings Pf the 2019 Edition. Unicef: 4. http://www.unicef.org/media/files/JME_2015_edition_Sept_2015.pdf.

WHO. 2014. WHA Global Nutrition Target 2025: Stunting Policy Brief. European journal of clinical nutrition, 92(1): 819-25. 